
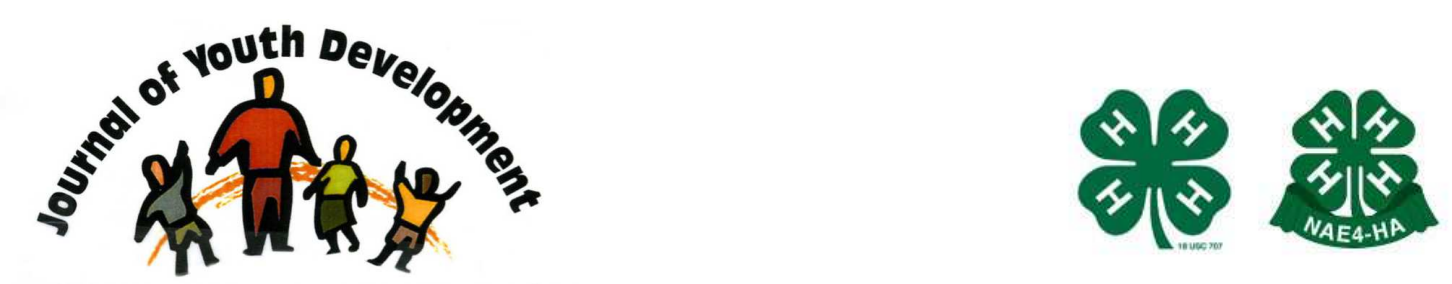

Bridging Research \& Practice

\title{
Preparing Adults to Work with Youth: An Environmental Scan of Professional Development
}

\author{
Jennifer Gerdes \\ University of Nebraska-Lincoln Extension \\ Lincoln, NE \\ jgerdes4@unl.edu \\ Tonia R. Durden \\ Department of Child, Youth \& Family Studies \\ University of Nebraska-Lincoln Extension \\ Lincoln, NE \\ tdurden2@unl.edu
}

Claudia C. Mincemoyer

Department of Agricultural Economics, Sociology \& Education

The Pennsylvania State University

University Park, PA

cxm324@psu.edu

Kathleen Lodl

University of Nebraska-Lincoln Extension

Lincoln, NE

klodl1@unl.edu 


\title{
JOURNAL OF YOUTH DEVELOPMENT \\ bridging research and practice

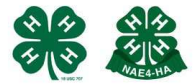

Volume 8, Number 2, Summer 2013

Article 130802FA002

\section{Preparing Adults to Work with Youth: An Environmental Scan of Professional Development}

\author{
Jennifer Gerdes, Tonia Durden and Kathleen Lodl \\ University of Nebraska-Lincoln Extension \\ Claudia C. Mincemoyer \\ The Pennsylvania State University
}

\begin{abstract}
This feature article shares the results of a national environmental scan conducted to identify professional development programs offered for school age providers across the nation through the Cooperative Extension System. A purposeful sample comprised of representatives from state extension offices throughout the country included 135 respondents from 48 states. Results showed 139 professional development programs for school age providers were offered through the Cooperative Extension System. The majority of programs offered professional development in the areas of health, nutrition, safety, youth development, and quality afterschool environments. This article summarizes the findings of the environmental scan, including number of contact hours, program scope, and program partners, as well as discussion and recommendations for future work in this area.
\end{abstract}

\section{Introduction}

4- $\mathrm{H}$ has a long-standing reputation and history of providing engaging, transformative and effective programming for participating youth. A longitudinal study of 7,000 adolescents found that youth who participated in 4-H programming excelled in school and contributed to their communities more so than their non 4-H peers (Lerner, \& Lerner, 2012). Researchers found that youth involved in 4- $\mathrm{H}$ contributed more to their communities and were more civically active than their non-4-H counterparts. 4- $\mathrm{H}$ youth also reported higher levels of academic competence and an elevated level of engagement at school. Lastly, youth who participated in 4-H were more likely to plan to go to college and pursue future courses in computer technology, science or engineering than their peers (Lerner, \& Lerner, 2012). 
Studies such as the Lerners' confirm that these successes are not serendipitous nor the result of more civic minded or academically talented youth enrolling in $4-\mathrm{H}$, rather a culminating result of youth learning more than academic content (Lerner, \& Lerner, 2012). 4-H provides opportunities for youth to develop and practice life skills through club experiences, project completion and leadership opportunities. Youth professionals and volunteers who work with 4-H youth focus on teaching $21^{\text {st }}$ Century skills such as decision-making, communication, goal setting, critical thinking and leadership. 4-H program activities, curricula and resources are then strategically planned and implemented to help 4- $\mathrm{H}$ members hone and enhance these skills. 4-H follows a theoretical framework of positive youth development and focuses it programs on three mission mandates; science, citizenship, and healthy living (National 4-H Headquarters, 2012). As a result of the wealth of teaching and experiential activities available, Cooperative Extension has arguably become a national leader in providing professional development for youth professionals and volunteers.

Historically, 4-H volunteers and professionals had a disciplinary focus (e.g. animal science, recreation, horticulture) and were not grounded in facilitating and teaching positive youth development and life skills. However, in 2004 a professional competency taxonomy was developed for $4-\mathrm{H}$ youth professionals and volunteers which changed this approach. These professional development competencies were organized into six domains of research-based knowledge known as the Professional Research Knowledge and Competencies Taxonomy (PRKC) that include youth program development, volunteerism, equity, access and opportunity; partnerships; and organizational systems (Heck, Subramaniam, \& Carlos, 2009). To assist 4-H professionals and volunteers in development, implementation and evaluation of youth programs in each of the three mission mandate areas, the United States Department of AgricultureNational Institute of Food and Agriculture (USDA-NIFA) and state Cooperative Extension systems provide professional development support. These professional development tools and resources are critical to assist adult professionals and volunteers in implementing researchbased programs that teach skills needed to maximize youth success. The tools, resources and professional opportunities available across these domains and the core areas include logic models, curriculum guides, lesson plans, rubrics, developmental guides, and evaluation (National 4-H Council, 2012b). An online learning community for professionals called $M y$ 4-H (https://www.my4-h.org) was recently established that allows adults working with youth to collaborate and connect with other volunteers and professionals across the country. Resources and programs are shared in this forum.

Given the positive outcomes for youth participating in $4-\mathrm{H}$ and the focus on positive youth development and teaching life skills, this study explored how the current professional development programming across the country helps support programming leading to these positive efforts. In this manuscript we present the findings from a national environmental scan identifying the school age professional development resources and programming currently implemented throughout the Cooperative Extension System. The scan specifically examined the scope and focus of the professional development programs offered to 4-H professionals and other youth-serving professionals and volunteers, including those in child care and other before $\&$ after school environments.

\section{Methods}

Under the auspices of a memorandum of agreement between USDA-NIFA and the Department of Defense Office of Family Policy/Children and Youth, the University of Nebraska-Lincoln 
Extension (UNL) conducted a national environmental scan of the professional development opportunities offered through the Cooperative Extension System to early childhood and school age providers (Author, Felix, Prokasky, Author \& Author, 2011). This article focuses on findings related to school age professional development programs. School age professional development programs were defined as those that provided learning opportunities for adults who worked with children ages 5-12 in before and after school child care and youth programs. This included teachers, administrators, para-professionals or other school staff, facilitators of after-school programs, and 4-H club leaders. The full report can be accessed at http://www.extension.unl.edu/web/child/cyttap.

\section{Sampling and Data Source}

The research team, consisting of Extension faculty and graduate students from UNL developed a questionnaire to determine a program's target audience, scope, goals, contact hours, delivery method, partnering agencies and evaluation strategies. A purposeful sample of Extension participants (faculty, directors, educators and other key leaders) who had knowledge of, or access to, the Extension programs offered within each state was identified.

The survey was piloted via phone interviews with participants from a separate project focused on childcare quality and access in thirteen states. Following the pilot of the survey, it was modified based on feedback for ease of use and expediting the data collection process (see appendix). The revised survey and an introductory letter about the environmental scan project were emailed to Extension contacts in the 37 remaining states. The research team made follow up phone calls weekly to increase the response rate. Data were ultimately collected from 48 states, with 30 of the 48 states reporting at least one professional development program for adults working with school age youth. The other 18 states reported only early childhood programming.

\section{Data Analysis}

Upon receipt of a state's information, the research team cleaned the data by removing typos, adjusting content area names and reformatting as needed. The edited survey was sent back to the respondents through a member checking process, which asked respondents to confirm, revise or add information (Lincoln, \& Guba, 1985). Nine of 48 states submitted revisions to their data. Frequency counts were recorded for target audience, content area, contact hours, scope of program, delivery method, and year program began.

Using descriptive analysis, the researchers identified the distribution, central tendency, and dispersion of data (Gravetter, \& Wallnau, 2007). States were allowed to report multiple responses for target audience, content area, scope of program and delivery method, therefore these numbers are duplicated counts. Curriculum name, contact hours and year the program began were unique responses and provide unduplicated counts of programming.

\section{Limitations of the Study}

Multiple methods were used to ensure the credibility and trustworthiness of the information collected in the environmental scan, including opportunities for participants to revise, edit and add information to data collected within their states through member checking. Additionally, reliability and validity of the qualitative analysis were addressed by appropriate preparation (skill/knowledge level) of the researchers, appropriate review of the existing literature, working inductively through the analysis, using appropriate methods and design, and leaving an audit trail such that an independent researcher could check the research events and decisions (Richards \& Morse, 2007). 
A limitation of the study is that the data rely on self-reporting and therefore only the data received from participants could be analyzed. It is also possible that the survey may not have reached all participants with knowledge of school age professional development occurring in their states. Furthermore, this environmental scan only asked about professional development programs and resources. Therefore, the findings do not provide a comprehensive picture of the array of other services and resources available through Extension to school age providers such as those provided on websites, through local publications or news briefs, or other outreach efforts of the Extension systems in each state.

\section{Results}

Respondents from 30 of the 48 states that submitted information for the environmental scan reported at least one professional development program for adults working with school age youth. Information was provided regarding each program's target audience, scope, goals, contact hours, delivery method, partnering agencies, and evaluation strategies.

\section{Number of Programs Offered}

Among the 30 states reporting school age programs a total of 139 professional development programs (29\% of all program reported) were targeted to professionals or volunteers working with school age youth (ages 5-12). States reported offering 1-17 professional development programs for school age professionals or volunteers, with an average of 4.56 programs per state (see Table 1).

Early childhood professional development programs constituted the remaining $71 \%$ of programs reported, accounting for substantially more than school-age professional development offerings. One possible explanation for the greater number of early childhood professional development programs offered through Cooperative Extension is that 4-H Youth Development programs have traditionally focused on providing direct service programs for youth rather than professional development for the adults working with youth.

Table 1

Number of School Age Professional Development Programs Reported

\begin{tabular}{|c|c|c|c|}
\hline $\begin{array}{c}\text { School Age } \\
\text { Professional } \\
\text { Development } \\
\text { Programs }\end{array}$ & $\begin{array}{c}\text { Number of Programs } \\
\text { Reported }\end{array}$ & $\begin{array}{c}\text { Average \# of } \\
\text { Programs per State }\end{array}$ & $\begin{array}{c}\text { Range of Number of } \\
\text { Programs per State }\end{array}$ \\
\cline { 2 - 4 } & 139 & 4.56 & $1-17$ \\
\hline
\end{tabular}

\section{Year Programs Began}

Interestingly, there was a dramatic increase in the number of new professional development programs for school age providers in 2005; five programs began in 2004, while 25 new programs were started in 2005 (see Figure 1). From 2005-2008 almost 47\% $(n=65)$ of reported school age professional development programs were started and zero new programs began in 2011. A possible explanation could include the decrease in access to federal grant funds targeting out-of school programming, in particular funding for $21^{\text {st }}$ Century Community Learning Centers. Additionally, many Extension systems felt the stress of federal, state, and local budget cuts that were occurring during this timeframe and possibly may have focused on direct service to youth to assure 4-H youth programs continued to operate. 
Figure 1

The number of school age professional development programs that began each year from $2000-2011$

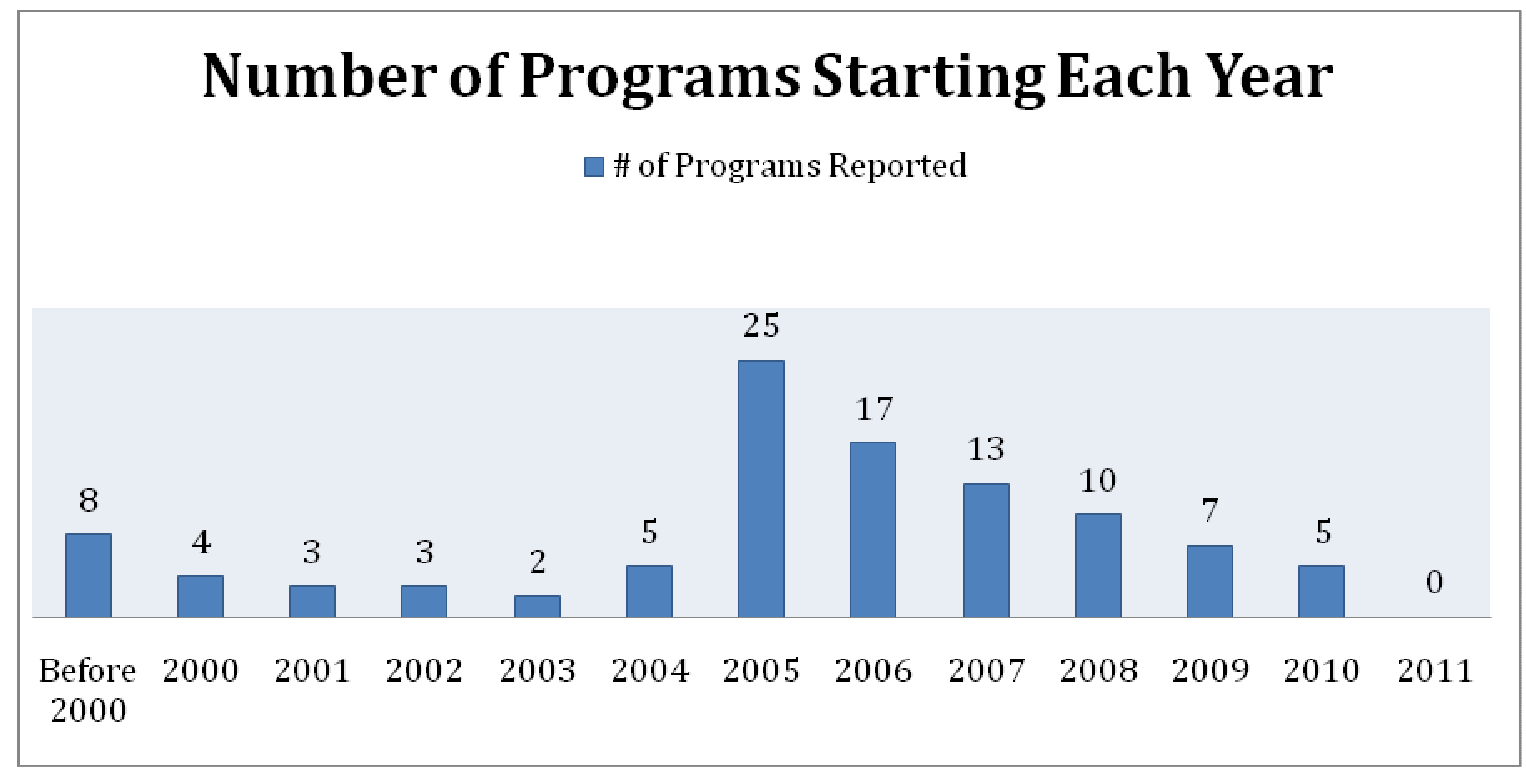

\section{Program Delivery}

The average number of contact hours for each participant during a program was 5.19 hours (see Figure 2). Thirty-nine percent of individuals received between one and three contact hours for each program and 16 percent received more than ten contact hours of professional development for their participation in a program.

Programs were delivered face-to-face or online with the majority $(n=129,85 \%)$ offered face to face and $16(11 \%)$ of programs offered online. Four percent of the programs were delivered in another format such as self-study or a hybrid (face to face \& online) delivery. However, the environmental scan did not ask respondents to identify the average number of trainings school age professionals attended or the average total hours of professional development obtained through Extension professional development. Such data could begin to document sequenced engagement and depth of learning that occurs through Extension. 
Figure $2 \mathrm{~N}=131$

The percentage of programs offering different amounts of contact hours

\section{Contact Hours of School Age Professional Development Programs}

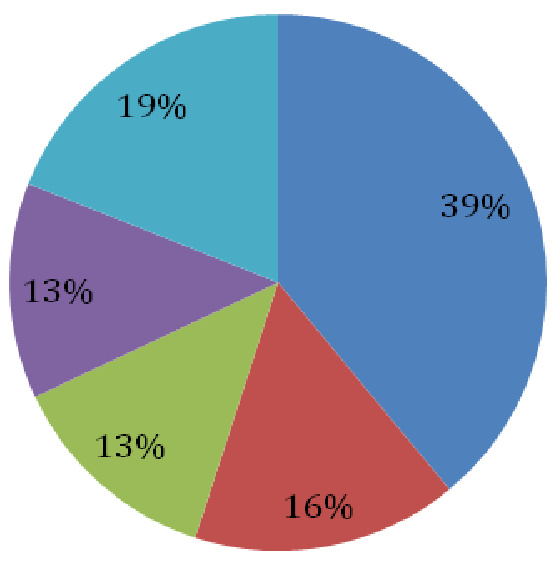

घ1-3 Hours

- 4-7 Hours

- 8-10 Hours

a $>10$ Hours

nours Vary

\section{Program Scope}

Of the programs identified in the scan, $19 \%$ were offered locally (e.g. one county or community in the state), and $72 \%$ of the programs were offered throughout the state (in multiple counties or all counties). A little more than $3 \%$ were offered in multiple states or nationwide (see Figure 3 ). While, there were a few key professional development programs that were utilized across states, the majority of the programs reported by each state were only available in most communities within a given state. 
Figure 2

The number of school age programs reporting different scopes of reach

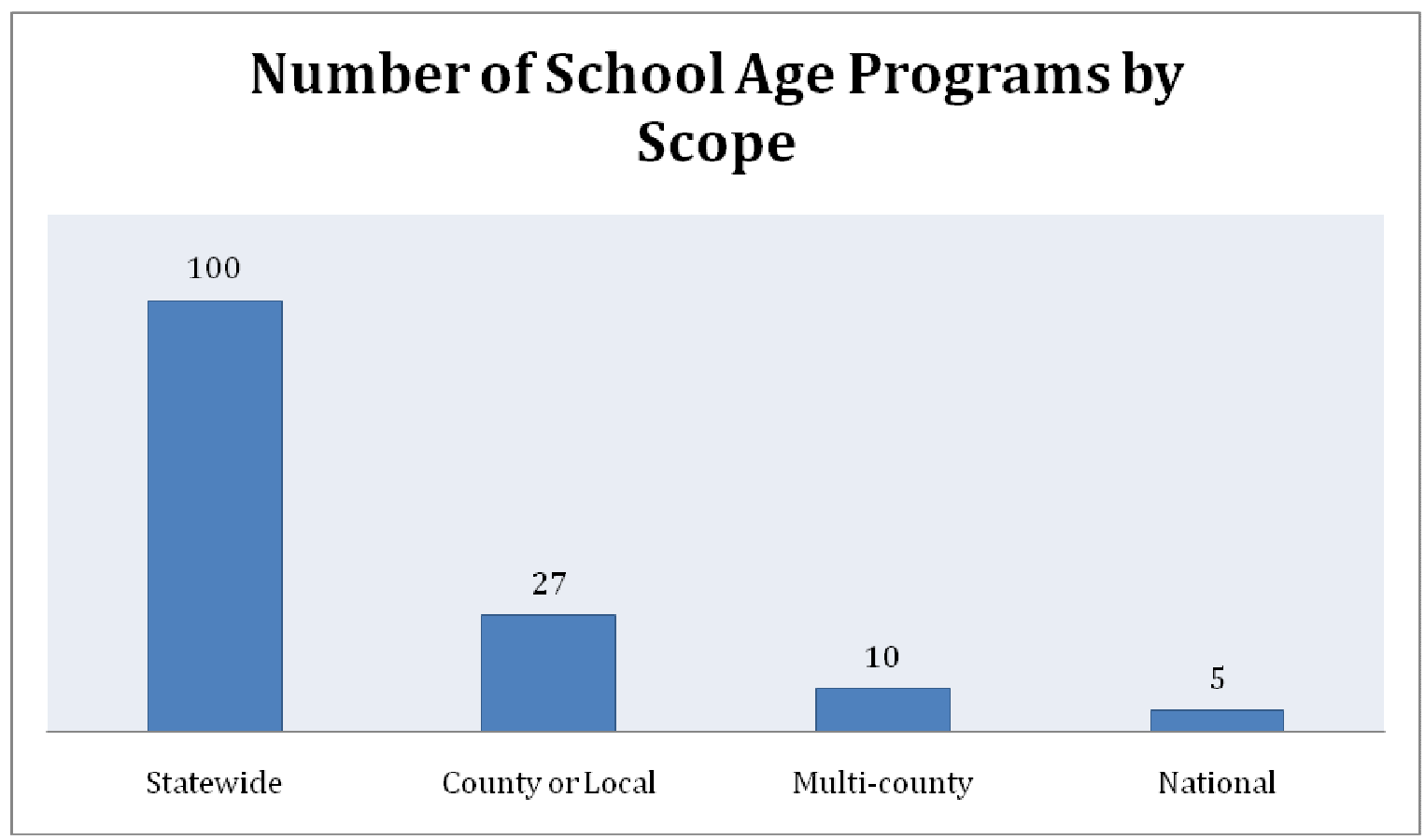

\section{Program Content}

From the responses of participants, the research team used coding and theme development to identify eleven broad content areas upon which the school age professional development focused. As represented in Figure 4 the most common content areas for school age trainings were nutrition, health, and safety, youth development, and quality afterschool activities and environments. Nutrition, health, and safety programs focused on topics such as obesity prevention, physical activity, food safety, and healthy lifestyles. Professional development programs that focused on youth development included topics such as citizenship, life skill development, and ages and stages of youth. Those programs that addressed quality afterschool activities and environments included topics such as classroom arrangement, inquiry based learning, and appropriate activities for school age children. 
Figure 3

The number of professional development programs under each content area.

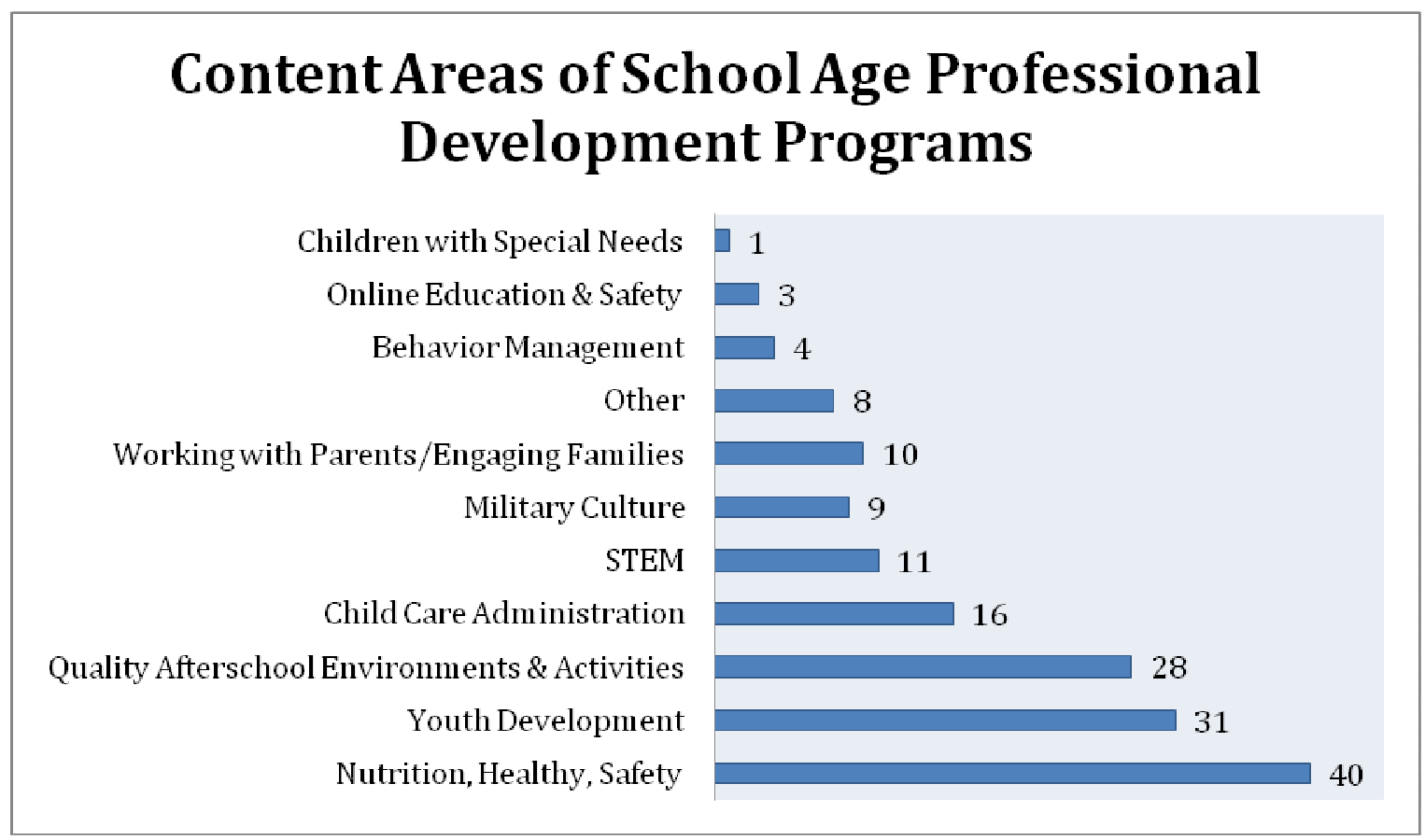

\section{Program Partners}

States reported working with a variety of public and private partners to provide professional development programs to school age providers (see Table 2). The most common partners reported at the local level included school districts, $21^{\text {st }}$ Century Community Learning Centers, and libraries. This indicates that professionals and volunteers, who are expected to help youth create, build and maintain partnerships within their communities, are intentionally modeling the value of partnership within local communities. Additionally, states reported partnering with agencies at both the state and national levels. State partners included state agencies, out of school networks, and military installations. States also reported partnering with national agencies such as MetLife and National 4-H. 
Table 2

Partners with whom Extension Works

\begin{tabular}{|ccc|}
\hline National Partners & $\begin{array}{c}\text { State Partners } \\
\text { National Association for the } \\
\text { Education of Young } \\
\text { Children (NAEYC) } \\
\text { Education, Licensing, Health } \\
\text { and Human Services, Head } \\
\text { Start State Collaboration } \\
\text { Office) }\end{array}$ & $\begin{array}{c}\text { School Districts (Private } \\
\text { and Public) }\end{array}$ \\
\hline Head Start & Out of School Networks & $\begin{array}{c}21^{\text {st }} \text { Century Community } \\
\text { Learning Centers }\end{array}$ \\
\hline MetLife & $\begin{array}{c}\text { Child Care Resource \& } \\
\text { Referral }\end{array}$ & Child Care Centers \\
\hline $\begin{array}{c}\text { Child and Adult Care Food } \\
\text { Program (CACFP) }\end{array}$ & Military Installations & Churches \\
\hline National 4-H & Private Institutes \& Funders & Libraries \\
\hline
\end{tabular}

\section{Program Evaluation}

Quality professional development program evaluation should document behavior change, focus on a set of skills and competencies, and be able to effectively evaluate program impact (Pianta, 2011). States reported program evaluation strategies for 102 of the 139 school age professional development programs. The two most frequently reported evaluation types were 1) pre/post evaluation and 2) post workshop evaluation. States did not report an evaluation strategy for 37 of the programs and it is unclear whether these programs did not conduct any evaluation for the program or if the respondent left the item blank for a different reason. Based on the information collected, it is unclear if programs reported are evidence or research based. Additionally, the majority of evaluation strategies reported measured knowledge change or intention to change behavior. Very few programs conducted follow-up evaluation with participants or included a comparison group that would provide the necessary information to indicate actual behavioral change.

\section{Discussion and Recommendations}

As demonstrated by the results of this national environmental scan of professional development for school age providers offered through the Extension system, there are many professional development programs that help adults increase their competency in understanding how young people learn and grow. These programs support adults in using this knowledge to develop responsive and supportive learning environments for the ultimate benefit of the youth they serve. Additionally, Extension is providing professional development using multiple strategies (face to face, online, \& hybrid) as well as offering a variety of time commitment options to individuals working with school age youth.

Enhancing healthy living habits of youth is an essential goal and programmatic focus in 4-H. Healthy Living programs "seek to address national issues including nutrition and physical fitness, substance abuse, safety, and social and emotional wellness" (National 4-H Conference Center, 2012c). In alignment with this key programmatic area, nutrition, health and safety was 
the most common content area for school age professional development trainings, indicating that training at the state and local level is responsive to national trends and foci.

Furthermore, one of the core competency areas for 4- $\mathrm{H}$ Youth Development indicates that professionals are expected to understand how young people learn and grow and then use this knowledge to develop responsive and supportive environments and learning opportunities. Given that youth development and quality afterschool learning environments and opportunities are two of the three most frequently offered types of professional development, it can be surmised that Extension is providing ample opportunities for adults who work with school age children to increase their competence in these areas.

Our findings suggest that Extension is partnering with other agencies and organizations to deliver professional development. However, more data are needed to determine the nature and intensity of these partnerships. Extension has a long history of volunteer and professional development focused on life skill development and creating positive youth development environments. Additionally, school age professionals and volunteers are intentionally modeling the value of partnerships for youth by engaging in partnerships at the local, state, and national levels. Professionals and volunteers are also utilizing non-traditional partnerships within communities such as intergenerational (child care centers; nursing homes), multi-cultural (cultural community centers), and non-profit service organizations (American Red Cross; Habitat for Humanity). These partnerships present opportunities for Cooperative Extension to help prepare youth professionals and volunteers to teach life skills and work with youth in positive ways. Establishing a network of national partners to encourage multi-state, regional and national partnerships between these entities and Extension is essential in enhancing efficiency and quality of the implemented professional development opportunities. National 4- $\mathrm{H}$ and eXtension have the potential to serve as the portal site for these collaborative efforts.

Of concern in our findings, however, is the progressive decline of new professional development programs being created and offered in states. While there was a peak in 2005, in 2011 across the 48 states that provided information there were no new professional development programs created for individuals who work with school age youth. This is a troubling finding given that Extension reaches more than 6 million youth each year through its programming (National 4-H Council, 2012a). Although possible explanations could include the decrease in access to federal grant funds targeting out-of school programming, as well as the stress of federal, state, and local budget cuts that were occurring during this timeframe it is imperative that attention be paid to this troubling finding and that professional development programs are evolving over time to better serve the adults working with youth day in and day out. Additionally, while a small percentage $(3 \%)$ of the programs identified in the scan were delivered nationally, a much larger portion of programs were being offered across whole states, but not nationally. Given the large percentage of programs developed at the state level there appears to be a need for a clearly defined process for state curricula to be adopted at the national level.

Furthermore, as strategies to enhance professional development to help youth develop into contributing and successful citizens are developed, youth-serving organizations must consider ways to promote and encourage the implementation of evidence based professional development programming. Based on our findings, training evaluation varies and behavior change is even less documented. Therefore, if the goal is to enhance the skills of our youth, we must intentionally document whether youth-serving professionals and volunteers have the necessary skills and knowledge to help youth reach these goals and more rigorous evaluation methods are needed. 
Extension has the ability to support the adults working with youth through quality professional development opportunities. Based on the current scope and reach of professional development programs offered by Cooperative Extension, the authors support three specific recommendations.

- First, the Cooperative Extension System must consider ways to reach more 4-H professionals and leaders by offering multiple modes of delivery such as face-to-face, online or on-site professional development and utilizing technology to reach adults who are in rural areas and have less access to resources in their communities. Another method of engaging participants that should be explored is using a coaching or professional learning community model.

- Secondly, states reported coordinating program efforts with multiple local, state and national partners. Therefore, establishing a network of national partners to encourage multi-state, regional and national partnerships between these entities and Extension would be essential in enhancing efficiency and quality in implementing professional development opportunities. National 4-H and eXtension can serve as the portal site for these collaborative efforts.

- Lastly, delivering quality, evidence based professional development for adults who work with 4-H youth is essential. Based on the findings from this environmental scan, states must consider how to utilize evaluation rubrics and measures established for youth programs for the professional development programs to demonstrate more rigorous program impact evaluation. This shift would allow programs to transition from researchinformed to evidence-based.

The environmental scan demonstrated that much is being done through the Cooperative Extension System to prepare the adults who work with school age youth. Youth serving professionals and volunteers have access to training that is offered for a variety of contact hours and in a variety of ways. Additionally, training is focused on societal needs such as supporting healthy habits. However, there is still work that can be done, especially in the areas of program evaluation, leveraging partnerships, and extending the reach of programming so that adults are better prepared to support the needs of school age youth, in whatever setting they find themselves.

\section{References}

Gerdes, J., Felix, D., Prokasky, A., Durden, T. R., \& Lodl, K. (2011). Community capacity building: Supporting military children and families: Environmental scan of Extension professional development opportunities for early childhood and school age providers. University of NebraskaLincoln Extension. Retrieved June 25, 2012 from http://www.extension.unl.edu/web/child/cyttap.

Gravetter, F.J., \& Wallnau, L.B. (2007). Statistics for the behavioral sciences (7th ed.). Belmont, CA: Thompson Wadsworth.

Heck, K., Subramaniam, A., \& Carlos, R. (2009). Use of the PRKC tool in assessment of staff development needs: Experiences from California. Journal of Extension. Retrieved February 6, 2013 from http://www.joe.org/joe/2009june/a7.php. 
Lerner, R.M., \& Lerner, J.V. (2012). The 4-H Study of Positive Youth Development. 2012 Summary of Findings from Wave 8. Retrieved October 10, 2012 from http://www.4h.org/about/youth-development-research/positive-youth-development-study/.

Lincoln, Y., \& Guba, E. (1985). Naturalistic inquiry. Newbury, CA: SAGE.

National 4-H Headquarters. (2012). Mission Mandates Fact Sheets. Retrieved on December 5, 2012 from http://www.national4-hheadquarters.gov/about/4h programs.htm.

National 4-H Council. (2012a). Who we are. Retrieved, November 26, 2012 from http://www.4-h.org/about/youth-development-organization/.

National 4-H Council. (2012b). Professional Development. Retrieved October 11, 2012 from http://www.4-h.org/about/youth-development-research/positive-youth-developmentstudy/.

National 4-H Council. (2012c). Healthy Living. Retrieved November 27, 2012 from http://www.4-h.org/youth-development-programs/kids-health/.

Pianta, R. (2011). Individualized and effective professional development supports in early care and education settings. Zero to Three. (32) 1, 4-10.

Richards, L., \& Morse, J. M. (2007). Readme First for a User's Guide to Qualitative Methods ( $2^{\text {nd }}$ ed). Thousand Oaks, CA: Sage.

(C) Copyright of Journal of Youth Development Bridging Research and Practice. Content may not be copied or emailed to multiple sites or posted to a listserv without copyright holder's express written permission. Contact Editor at: patricia.dawson@oregonstate.edu for details. However, users may print, download or email articles for individual use.

ISSN 2325-4009 (Print); ISSN 2325-4017 (Online) 


\begin{tabular}{|c|c|c|c|c|c|c|c|c|c|}
\hline \multicolumn{10}{|c|}{ Appendix } \\
\hline \multicolumn{10}{|c|}{ Extension Resources for Early Childhood and School Age Professional Development } \\
\hline $\begin{array}{l}\text { Curriculum } \\
\text { Name }\end{array}$ & $\begin{array}{c}\text { Target } \\
\text { Audience }\end{array}$ & Content & $\begin{array}{l}\text { Goal and } \\
\text { Objectives }\end{array}$ & $\begin{array}{c}\text { Contact } \\
\text { Hours }\end{array}$ & $\begin{array}{l}\text { Scope of } \\
\text { Program } \\
\text { (County, } \\
\text { Local, } \\
\text { Statewide) }\end{array}$ & $\begin{array}{l}\text { Delivery } \\
\text { Method } \\
\text { (Face to } \\
\text { Face or } \\
\text { Online) }\end{array}$ & $\begin{array}{l}\text { Year } \\
\text { Began }\end{array}$ & Partners & Evaluation \\
\hline $\begin{array}{l}\text { Working } \\
\text { with } \\
\text { Military } \\
\text { Families* }\end{array}$ & $\begin{array}{l}\text { Childcare } \\
\text { Providers }\end{array}$ & $\begin{array}{l}\text { Working } \\
\text { with } \\
\text { Military } \\
\text { Families }\end{array}$ & $\begin{array}{l}\text { Increasing childcare } \\
\text { provider knowledge of } \\
\text { stressors experienced by } \\
\text { military families, and how } \\
\text { to identify issues and best } \\
\text { work with parents }\end{array}$ & 3 hours & $\begin{array}{l}\text { Multi } \\
\text { County }\end{array}$ & $\begin{array}{l}\text { Face } \\
\text { to } \\
\text { Face }\end{array}$ & 2011 & None & $\begin{array}{l}\text { Pre- and } \\
\text { post- } \\
\text { testing }\end{array}$ \\
\hline 4-H* & $\begin{array}{l}\text { Youth } \\
\text { Program } \\
\text { Leaders }\end{array}$ & & $\begin{array}{l}\text { Provide training to youth } \\
\text { programming staff to } \\
\text { understand youth } \\
\text { development and } \\
\text { implement 4-H Curricula } \\
\text { and other programs }\end{array}$ & varies & $\begin{array}{c}\text { Statewide } \\
\text { County }\end{array}$ & $\begin{array}{l}\text { Face } \\
\text { to } \\
\text { Face }\end{array}$ & 1996 & $\begin{array}{l}\text { Army } \\
\text { Navy } \\
\text { Air } \\
\text { Force }\end{array}$ & $\begin{array}{l}\text { Individual } \\
\text { Workshop } \\
\text { Evaluation }\end{array}$ \\
\hline
\end{tabular}

